\title{
Research based on mathematical modeling of CHP-10 power unit No 5 "Baikal Energy Company" LLC to assess the efficiency of its modernization
}

\author{
Fedor Zabuga ${ }^{1,2}$, Vitalii Alekseiuk ${ }^{1 *}$ \\ ${ }^{1}$ Melentiev Energy Systems Institute of Siberian Branch of the Russian Academy of Sciences, Irkutsk, Russia \\ ${ }^{2}$ Baikal Energy Company LLC, Irkutsk, Russia
}

\begin{abstract}
The work aims to study the effect of changes in the drain scheme of the low-pressure regeneration on the energy and economic efficiency of the CHP plant-10 power unit No 5 of "Baikal Energy Company" LLC. In this study, we used a mathematical model of the power unit adjusted to the measurements results. The mathematical modelling of the power unit was performed using the "Computerassisted programming system" application package. The created mathematical model of the heat and power plant was tailored to the current state of the study object according to the threestage identification procedure of the mathematical model parameters. We proposed a cycle arrangement under which three streams of the low-pressure drainages were redirected to the pump suction of the low-pressure heater. The improved mathematical model of the power unit allows the calculation of the parameters of both the existing and proposed cycle arrangements. According to the calculations, the temperature difference between the main condensate after the low-pressure heater 1 and the investigated drains after mixing is minimal and amounts to $3.2{ }^{\circ} \mathrm{C}$. The suggested modernisation increases the energy efficiency of the power unit by $0.007 \%$ under the nominal operating conditions of the existing and proposed thermal circuit. In addition, the specific standard fuel consumption for electric generation is reduced by 0.052 gram of conventional fuel $/ \mathrm{kW} \cdot \mathrm{h}$. The operating costs to implement the proposed engineering solutions amounted to 34191 roubles. Considering the annual power plant extensive consumption factor, the payback period of the proposed modernisation will be 5.5 months. The savings for the first operation year are estimated at 18423 roubles, based on the rate of return and depreciation expenses. The proposed approach combines mathematical modelling of operating power plants with a technique of increasing the efficiency of technical decision-making. The proposed versatile approach can be used for the modernisation of CHPs and other plants.
\end{abstract}

Keywords: coal-fired power unit, efficiency improvement, technical solution, mathematical modeling, condensing unit, heat flow.

\section{Introduction}

Improving the efficiency of the burned fuel using in power plants is one of the most important tasks facing the modern energy industry. Currently, thermal power plants that were designed and put into operation in the middle of the last century continue to be operated. The technical solutions adopted at that time often do not meet modern requirements, which are due to the existing relationship between fuel prices and equipment. For this reason, many thermal power plants have significant reserves for saving fuel and energy resources. The discovery of these reserves and the development of the most effective modes of operation of thermal power plants are possible on the basis of comprehensive studies of power equipment for real conditions of its operation. The combined application of the technique of complex analysis of the effectiveness of technical solutions [1] and the methods of mathematical modeling and circuitparametric optimization [2] can be very effective for solving this problem. The fundamental advantages of mathematical models are the ability to quickly, accurately and repeatedly solve the problem under different conditions, and to quickly make changes to the calculation method. These opportunities have predetermined their wide distribution in the development and design of electric and thermal energy sources.

In addition to the steam flow that expands in the lowpressure part, additional steam-water flows that have a higher temperature than the steam condensation temperature in the condenser enter the condensers of steam turbine plants. The excess heat of these streams is removed with the cooling water and is not usefully used. These flows include recirculation of the main

* Corresponding author: alexeyuk.vitaliy@yandex.ru 
condensate, drains of the turbine bleeds and cylinders, suction of the steam-air mixture and discharge of condensate from heaters, low-pressure cylinder seals, and others [3].

This problem was studied in detail in $[4,5]$. The authors conclude that the calculated value of the heat consumption, for example, with recirculation of the main condensate for heating turbines with a capacity of 50$200 \mathrm{MW}$ is 2.5-7 MW, and the actual level of the specified heat consumption in real operating conditions exceeds the calculated value by $1.5-2.5$ times. The total amount of heat entering the condenser in addition to the low-pressure part is 8-18 MW.

In the work of Merkulov V.A. [6], the influence of the recirculation flow of the main condensate on the efficiency of the steam turbine plants operation is investigated. This heat flow is heated in a number of low-pressure turbine heaters and in certain operating modes of steam turbines PT-80/100-130/13, T-100/120$130-3$, PT-135/165-130/15 is discharged into the capacitor. The necessity of working with open recirculation is the technological necessity of the minimum flow of the main condensate through the refrigerators of the main turbine ejectors and the seal ejectors for their normal operation. If the steam flow rate at the outlet of the low-pressure part of the above turbines is less than $70 \mathrm{t} / \mathrm{h}$, due to the conditions of continuous operation, the recirculation of the main condensate during this period of operation should be switched on. To reduce heat losses with recirculation of the main condensate and increase the thermal efficiency of steam turbines, the author suggests transferring the cooling of the main ejectors, seal ejectors and oil seal heater from the main condensate to chemically desalinated water. Modernization of the main condensate recirculation scheme at the PT-135/165-130/15 turbine unit of Dzerzhinskaya CHP (plant No. 6) allowed to obtain a reduction in heat losses by 21000 GJ per year with a duration of operation in these modes of 3800 hours [6].

The ways of modernization of the thermal scheme of the $300 \mathrm{MW}$ power units of the Kostromskaya GRES proposed by Velikorossov V.D. make it possible to increase the efficiency of its operation [7]. The author, in addition to other changes in the thermal scheme, determined the heat flow of the low pressure heater (LPH-1) working steam drain, which in the scheme in force at that time merged into the turbine condenser. Redirecting the drainage of the LPH-1 in the mixture located between the condenser and the condensation electric pumps (CEP) - at the CEP suction allowed to reduce the heat loss with hot drainage in the condenser. The total power change was $230 \mathrm{~kW}$ [7].

It should be noted that the above-mentioned works did not use mathematical models of the entire power plant. The lack of measurements of a number of operating parameters of the low-pressure regeneration of the turbine unit makes it difficult to perform the required calculations. Obtaining these measurements can be performed during special tests of the installation with the involvement of specialized organizations, and this in turn requires additional financial costs. The mathematical model of the power plant, configured in accordance with the identification method, allows performing the necessary calculations with high accuracy and finding optimal solutions with their help. Moreover, the mathematical model of the installation provides an opportunity to quickly assess the effect of several jointly performed circuit upgrades. It should also be noted that the difference of this work is the modernization, which includes only the redirection of heat flows without introducing new elements of power equipment into the scheme.

It should be borne in mind that one of the principles of making certain technical decisions is a comprehensive analysis of their effectiveness. Optimal in the field of production, are the solutions that contribute to the greatest increase in its efficiency. This efficiency is determined in relation to the costs required to achieve it. In this paper, we consider the possibility of upgrading the current scheme of the power unit No. 5 of the CHP10 of "Baikal Energy Company" LLC. In the thermal scheme of the power unit, the authors identified a number of drains that reduce the efficiency of its operation. A comprehensive analysis of the effectiveness of the proposed changes in the thermal scheme was carried out in three stages.

The identification of technical feasibility serves as the first stage of a comprehensive analysis. The second stage of the analysis is engineering and economic calculations. However, the practice of applying industryspecific methods of technical and economic calculations shows that they do not adequately reflect the features of the economic assessment of the design and reconstruction of power plants, individual measures for the technical operation and repair of power plants. Therefore, it is of scientific interest to develop additional methods and recommendations related directly to the assessment of the economic efficiency of design, technological and organizational and technical developments in the field of operation of technical means, devices and systems.

Taking this into account, in this paper, a detailed mathematical model is used to evaluate the effectiveness of the proposed changes, which is adjusted with sufficient accuracy to the actual operating modes of the equipment. To identify the parameters, we used a threestage method developed in the Department of Heat and Power Systems ISEM SB RAS to identify the parameters of power equipment operation [8-10]. During long-term operation, the thermal characteristics of the auxiliary equipment that is part of the power plants change and there are differences from the characteristics determined by the manufacturer. Therefore, when mathematical modeling of existing power plants requires their configuration, taking into account the current state of the equipment based on the results of measurements of control parameters performed in several steady-state operating modes. This technique allows you to adjust the coefficients of the mathematical model in such a way that the results obtained using the mathematical model correspond as closely as possible to the actual state of the equipment, which ensures the validity of optimization decisions. 
Optimization calculations required to identify the mathematical model were made by a modified gradient method developed at ISEM SB RAS [11-13]. This method of solving systems of nonlinear equations unlike works of foreign authors [14-18] allows solving optimization problems of large dimensions (hundreds of optimizable parameters, thousands of restrictionsequalities and restrictions of inequalities) with high accuracy.

The final stage is a comprehensive comparative analysis of the current and upgraded thermal scheme of the power unit according to generalized economic indicators, taking into account the criteria of operational reliability, and the formulation of conclusions.

\section{Detection of the technical feasibility of the proposed technical solutions}

In the current thermal scheme of power unit No. 5, three heat flows were identified, which reduce its efficiency. The drainage of the seal ejector SE-5 introduced into turbine condenser. The technical characteristics of the seal ejector are shown in Table 1.

Table 1. Technical characteristics of seal ejector SE-5 [19].

\begin{tabular}{|l|c|}
\hline \multicolumn{1}{|c|}{ Parameter } & Value \\
\hline Consumption of the sucked mixture, $\mathrm{kg} / \mathrm{s}$ & 0,354 \\
\hline Including a couple, $\mathrm{kg} / \mathrm{s}$ & 0,117 \\
\hline Including air, $\mathrm{kg} / \mathrm{s}$ & 0,238 \\
\hline Working steam consumption, $\mathrm{kg} / \mathrm{s}$ & 0,1 \\
\hline Cooling condensate flow rate, $\mathrm{kg} / \mathrm{s}$ & 41,67 \\
\hline Cooling condensate pressure, $\mathrm{MPa}$ & 1,37 \\
\hline \begin{tabular}{l} 
Cooling condensate temperature, ${ }^{\circ} \mathrm{C}$ \\
\hline $\begin{array}{l}\text { Pressure of the suction mixture at the inlet, } \\
\mathrm{MPa}\end{array}$
\end{tabular} & 0,09 \\
\hline $\begin{array}{l}\text { Pressure of the suction mixture at the } \\
\text { outlet } \mathrm{MPa},\end{array}$ & 0,1 \\
\hline
\end{tabular}

The drainage flow rate of the SE-5 is $0.217 \mathrm{~kg} / \mathrm{s}$. It is defined as the sum of the working steam consumption and the steam component of its passport productivity. During the research, the temperature of the pipe wall through which the heat flow under consideration flows was measured. The temperature was $70{ }^{\circ} \mathrm{C}$. The measurement was performed at the service site of the condensate pump CEP-5 in the area of the steam turbine condensate collector.

The drainage of the main ejectors ME-5A,B is brought into the steam space of the condenser in the current scheme. It should be noted that the drainage flow rate during the operation of the existing equipment differs from the passport one ${ }^{1}$. The nominal flow rate of the working steam of $0.167 \mathrm{~kg} / \mathrm{s}$ is provided at an operating pressure of $0.59 \mathrm{MPa}$.

\footnotetext{
${ }^{1}$ Operating Manual for Steam Turbine K-160-130 CHP-10
}

In practice, due to the presence of air suckers in the vacuum system-the increased leakiness of the vacuum system, the pressure of the working steam in front of the ejectors must be maintained within $0.98-1.08 \mathrm{MPa}$, the two main ejectors are constantly in operation. The consequence of this is a proportionally increasing consumption of working steam. The drainage flow rate of ME-5A,B was defined as the total double passport flow rate of working steam and the total passport capacity for steam. The total drainage flow rate is 0.668 $\mathrm{kg} / \mathrm{s}$. The pipe wall temperature was measured on the drainage pipeline of the main ejectors of the block. The wall temperature was $50{ }^{\circ} \mathrm{C}$.

The drainage of the heating line of the block reduction-cooling unit (BRCU-2) of the boiler unit (BU) No. 9 of the power unit No. 5 is installed in the lower part of the condensate collector and is necessary to maintain the "dead-end" section of the hot industrial superheat pipeline in front of the closed BRCU-2 in a heated state. In the current scheme, the parameters of the steam at the entrance to the studied heat flow are assumed to be equal to the parameters of the steam of the BU-9 hot industrial superheat. The heating line, with an internal diameter of $10 \mathrm{~mm}$, cuts into the drainage of the pipeline of the BRCU-2 heat compensator with a diameter of $32 \mathrm{~mm}$. The transition to a smaller diameter is made to reduce the consumption of the "heating" drainage and, as a result, reduce heat loss in the steam turbine condenser. The drainage flow rate is determined from the classical formula of the gas velocity in the gas pipeline $^{2}$, using the values of the pressure and temperature of the working medium, as well as the internal diameter of the pipeline. As a result of the calculation, the drainage flow rate is $0.128 \mathrm{~kg} / \mathrm{s}$.

Problem statement. The physical meaning of the problem is the irretrievable loss of heat from the drainage flows with cooling water and, as a result, a decrease in the efficiency of the equipment. In the current scheme, the hot drains SE-5 with a temperature of $70{ }^{\circ} \mathrm{C}$; ME-5A,B with a temperature of $50{ }^{\circ} \mathrm{C}$ are discharged into the steam turbine condensate collector according to the principle of a cascade scheme, in which the drainage is removed by gravity from the heater with a higher pressure to the heater with a lower pressure, and then into the turbine condenser. As a result, there is a loss of heat with a "hot" drainage, diverted to the condenser, where this heat is given to the cooling water.

The combined heat economy drainage scheme is more efficient than the cascade scheme. Cascade scheme is used in the current thermal scheme in relation to the condensate of heating steam LPH-1,2,3,4. It is proposed to apply the principle of the combined scheme for the heat flows of the drains SE-5 and ME-5A,B and include the above-mentioned heat flows in the existing combined scheme, for which they should be redirected to the suction of the LPH-1 drainage pump, abandoning their cascade discharge into the condenser. This choice is based on the following principle: to ensure the greatest thermal efficiency, the condensate from the heaters and

\footnotetext{
${ }^{2}$ Handbook for the design of trunk pipelines / under. ed. A.K. Derktsakyan. L.: "Nedra", Leningrad department, 1977, 520 p.
} 
the main condensate of the turbine should be mixed under conditions that correspond to the greatest approximation to the reversible mixing process, i.e. at the lowest temperature difference. If this condition is met, there will be no increase in the condensation output and the thermal efficiency of the cycle will increase due to a decrease in losses in the turbine condenser [20].

Figure 1 shows the current and modified thermal schemes of power unit No. 5. In the presented diagram, the red color shows the directions of the thermal flows of the drains in the current scheme, which are brought into the turbine condenser, and the green color shows the proposed changes.

The calculation of the mathematical model shows that the temperature of the main condensate for LPH-1 is $56.7^{\circ} \mathrm{C}$; the temperature of the drains SE-5, ME-5A,B and LPH-1 after mixing is $53.5{ }^{\circ} \mathrm{C}$. We can conclude about the effectiveness of the chosen path of the direction of the drainage flows under consideration, since the temperature difference between the main condensate for LPH-1 and the drains after mixing is minimal and amounts to $3.2{ }^{\circ} \mathrm{C}$.

The heat flow of the drainage heating line of the pipeline BRCU-2 of the BU-9, in contrast to the abovementioned low-potential flows, is a flow with a high potential of the heat accumulated in it, which is uselessly lost in the condenser. Its redirection to the steam space LPH-1 will lead to a decrease in the flow rate of working steam to the turbine outlet 8 , which "feeds" PND-1. This will happen due to the displacement of the extracted steam by the drainage with a higher pressure. As a result, the condensing power generation of the last compartment of the steam turbine's central heating system will increase. As a result, the heat of this drainage will be stored in the block cycle and more steam will perform useful work in the last compartment of low pressure cylinder.

It should also be noted that the proposed modernization of the thermal scheme will allow maintaining the required operational reliability of the power plant under consideration without making additional changes to the current scheme. The performance of the LPH-1 drainage pump, as well as the throughput capacity of the LPH-1 emergency drainage overflow pipeline to the condenser, will allow to exclude an emergency level rise in all operating modes in cases of abnormal operational situations, taking into account the additional drainage flow rate of the studied flows.

\section{Engineering and economic calculations using a customized mathematical model of the power unit}

It is very difficult to give a correct assessment of the above-described change in the direction of thermal currents, without using the methods of modern mathematical modeling of processes occurring in STP. All the studies and calculations presented in this paper were performed on the mathematical model of the condensation double unit No. 5, which is part of the main equipment of the CHP-10 of "Baikal Energy
Company" LLC. A detailed mathematical model of the power unit was constructed by the software and computing complex "System of machine program construction" developed at ISEM SB RAS [21,22].

The power unit model consists of models of two boiler units and a turbine unit connected by steam and water connections. The design scheme of the power unit includes 121 elements and 198 connections between them. The resulting mathematical model contains 1297 information-input, 1457 information-output parameters, of which 132 parameters are iteratively calculated and require an initial approximation.

To determine the adjustable coefficients of the mathematical model of the power unit under study, a three-stage method for identifying the parameters of the mathematical models of the thermal power plant developed at ISEM SB RAS was used [8-10]. This method provides for the exclusion of "bad" measurements of control parameters at the first stage of identification, the errors of which go far beyond the accuracy class of the measuring instruments used. Further, at the second stage of identification, the maximum relative discrepancy between the parameters measured at the installation and the parameters obtained during the calculation of the mathematical model of the power unit is optimized. The optimal value of the maximum relative residual of the measured parameters was 2.90. This value satisfies the accuracy condition according to the "rule $3 \sigma$ " $[23,24]$. Since the confidence probability in this case is 0.997 , all random errors of the measured parameters can be explained by the imperfection of the measuring devices used. At the third stage of identification, the sum of the squares of all relative residuals of the measured parameters was optimized to achieve the best accuracy of the convergence of the developed mathematical model with the current operating modes of the current installation.

Measurements of the operating parameters of power unit No. 5, necessary for the identification of its mathematical model, were performed during the operation of the equipment in the fall of 2018. During the 12-hour working shift, the parameters were measured for the steady-state operating modes with an electrical load of 140, 132 and $108 \mathrm{MW}$. In the time intervals between the measurements of the parameters, no work was carried out that may affect the condition of the equipment: drying the pipe boards of the turbine condenser, blowing the heating surfaces of boilers, etc. The temperature of the cooling water at the inlet to the steam turbine condenser and the atmospheric air pressure remained unchanged during the measurements. 


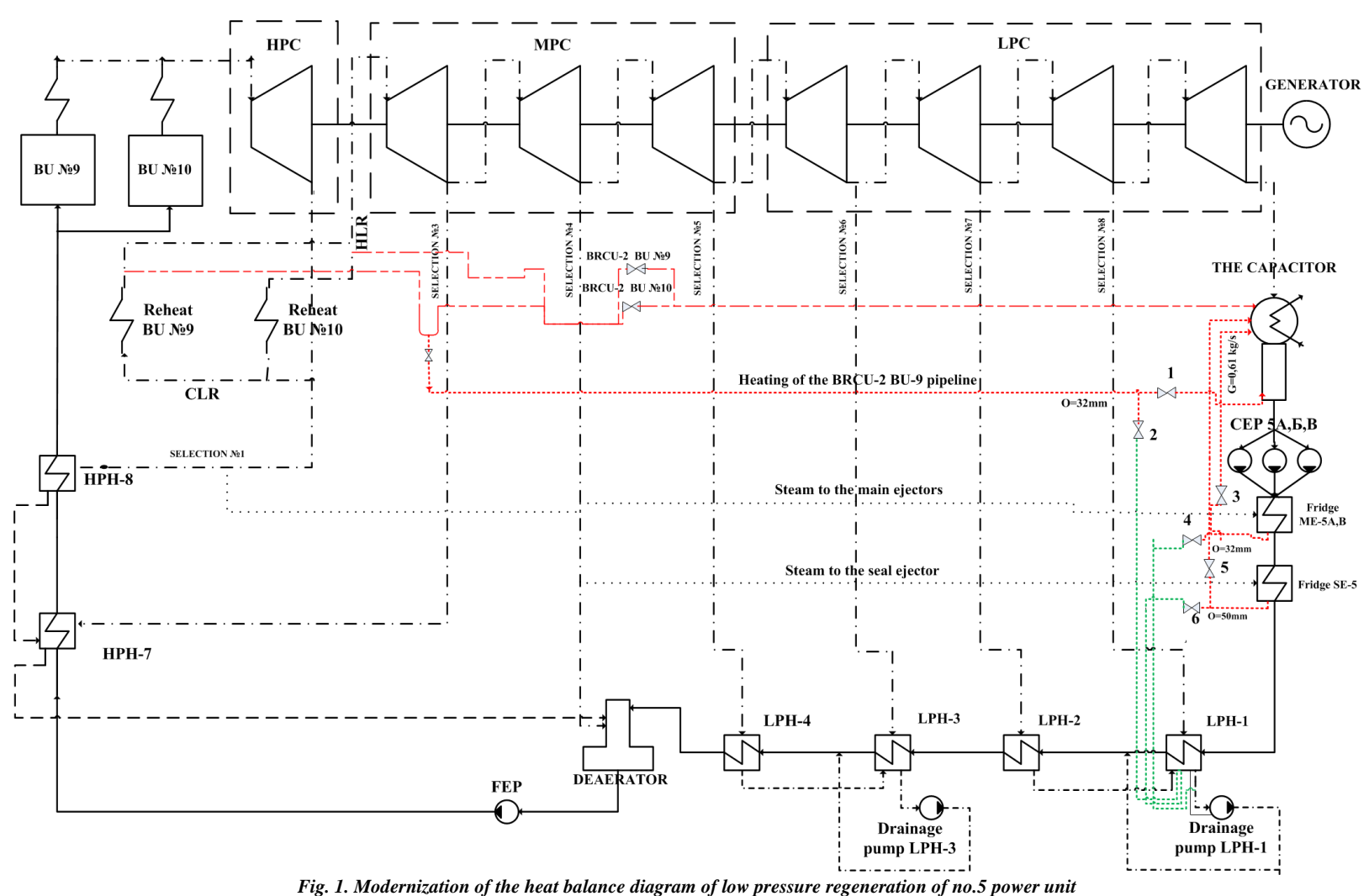

Note: CLR - cold line of reheat, HLR - hot line of reheat, HPC - high-pressure cylinder, MPC - medium-pressure cylinder, LPC - low-pressure cylinder, CEP - condensation electric pump, FEP - feed electric pump, LPH - low-pressure heater, HPH - high-pressure heater, BU - boiler unit, BRCU - block reduction-cooling unit 
In practice, it is proposed to maintain the current thermal scheme and simultaneously implement the proposed redirection of heat flows in the drains of lowpressure regeneration heaters. Maintaining the current thermal scheme is necessary in cases of disconnection of the first group of LPH on the working turbine, as well as the withdrawal for repair or emergency shutdown of the LPH-1 drainage pump. New fittings are added to the diagram: valve 1 - drainage of the pipeline of the BRCU-2 BU-9 thermal compensator in the turbine condenser; valve 2 - drainage of BRCU-2 in LPH-1; valve 3 - drainage of ME-5A,B in the turbine condenser; valve 4 - drainage of OE-5A,B in LPH-1; valve 5 drainage of SE-5 in the turbine condenser; valve 6 drainage of SE-5 in LPH-1. It is advisable to place the valves "1" and "2" in close proximity to the condensate collector for ease of operation.

The heat flow of the drainage of the main ejectors of the block is proposed to be started on the suction pump of the LPH-1 drainage pump-cut into the pipeline between the LPH-1 and the pump. Variant calculations of the mathematical model show that the drainage temperature of the main ejectors in all operating modes does not exceed the saturation temperature in LPH-1, therefore, its boiling is excluded. The heat flow of the drainage of the seal ejector is proposed to be brought into the steam space of the LPH-1 under the level of the condensate of the heating steam. Initially, the proposed solution, which is simpler from the point of view of installation, to choose the direction of the LPH-1 drainage pump to the suction can lead to its unstable operation [25]. From the calculations of the mathematical model, it can be seen that the drainage temperature of SE-5 exceeds the saturation temperature in LPH-1 in certain operating modes of the turbine, therefore, it is possible to boil the drainage at the pump suction, which is unacceptable, since it can lead to "steaming" of the pump. For the same reason, the heat flow of the heating pipeline of the BRCU-2 BU-9 heat compensator is proposed to be brought into the steam space of the LPH-1 under the level of the condensate of the heating steam.

Table 2 shows the results of calculations of the mathematical model of the power unit No. 5 for the current and modified thermal circuit for the operation mode with an electric load of $140 \mathrm{MW}$ at the generator.

Table 2 .The results of variant calculations of the current and modified thermal scheme of the energy block.

\begin{tabular}{|c|c|c|c|c|}
\hline Parameters, units of measurement & $\begin{array}{l}\text { Current } \\
\text { thermal } \\
\text { scheme }\end{array}$ & $\begin{array}{l}\text { Redirection of } \\
\text { SE-5 and ME- } \\
5 \mathrm{~A}, \mathrm{~B} \text { drainage } \\
\quad \text { flows }\end{array}$ & $\begin{array}{l}\text { Redirection of } \\
\text { heating lines } \\
\text { BRCU-2 flow }\end{array}$ & $\begin{array}{l}\text { Joint } \\
\text { redirection of } \\
\text { the studied } \\
\text { heat flows }\end{array}$ \\
\hline $\begin{array}{l}\text { Electrical power at the generator terminals, } \\
\text { MW }\end{array}$ & 136,225 & 136,231 & 136,240 & 136,244 \\
\hline Steam pressure in the condenser, $\mathrm{kPa}$ & 5,3836 & 5,3835 & 5,3828 & 5,3827 \\
\hline $\begin{array}{l}\text { The temperature of the exhaust steam at the } \\
\text { outlet of the central heating system, }{ }^{\circ} \mathrm{C}\end{array}$ & 34,2184 & 34,2179 & 34,2157 & 34,2155 \\
\hline Steam consumption in the condenser, $\mathrm{kg} / \mathrm{s}$ & 91,29 & 91,33 & 91,43 & 91,47 \\
\hline Steam consumption per LPH-1, kg/s & 2,332 & 2,306 & 2,296 & 2,268 \\
\hline $\begin{array}{l}\text { Electrical power of the LPC-4 compartment, } \\
\text { MW }\end{array}$ & 12,613 & 12,625 & 12,652 & 12,662 \\
\hline $\begin{array}{l}\text { The temperature of the main condensate at the } \\
\text { entrance to the LPH- } 1,{ }^{\circ} \mathrm{C}\end{array}$ & 41,641 & 41,717 & 41,637 & 41,711 \\
\hline $\begin{array}{l}\text { The temperature of the main condensate at the } \\
\text { outlet of LPH- } 1,{ }^{\circ} \mathrm{C}\end{array}$ & 56,695 & 56,759 & 56,693 & 56,746 \\
\hline $\begin{array}{l}\text { Drainage temperature at the outlet of the LPH- } \\
1 \text { drainage pump, }{ }^{\circ} \mathrm{C}\end{array}$ & 52,714 & 53,547 & 52,661 & 53,534 \\
\hline $\begin{array}{l}\text { Drainage flow rate at the outlet of the LPH-1 } \\
\text { drainage pump, } \mathrm{kg} / \mathrm{s}\end{array}$ & 5,303 & 6,266 & 5,269 & 6,232 \\
\hline Net efficiency of the power unit, $\%$ & 33,386 & 33,389 & 33,392 & 33,393 \\
\hline $\begin{array}{l}\text { Specific consumption of conventional fuel for } \\
\text { electricity generation (net), gram of } \\
\text { conventional fuel } / \mathrm{kW} \cdot \mathrm{h}\end{array}$ & 367,975 & 367,958 & 367,932 & 367,923 \\
\hline
\end{tabular}


The results of variant calculations of the mathematical model show that redirecting the heat flows of the drains of the main ejectors and the seal ejector of power unit No. 5 will reduce the specific consumption of conventional fuel for generating $1 \mathrm{~kW} \cdot \mathrm{h}$ of electricity by 0.017 grams. Redirecting the heat flow of the heating line of the BRCU-2 BU-9 will reduce the specific consumption of conventional fuel for the production of 1 $\mathrm{kW} \cdot \mathrm{h}$ by 0.043 grams. The joint redirection of the above-mentioned heat flows from the steam turbine condenser to the LPH-1 will lead to a decrease in the specific consumption of conventional fuel for the production of $1 \mathrm{~kW} \cdot \mathrm{h}$ by 0.052 grams.

Table 3 shows the investment required for the purchase of pipes of the appropriate diameters ${ }^{3}$ and shutoff valves ${ }^{4}$, as well as the cost of their installation work $^{56}$. Table 3 shows that in order to implement the proposed modernization in practice, it is necessary to spend 26883 rubles for the purchase of fittings and pipes of appropriate diameters and 7308 rubles for installation work. The total cost of the project will amount to 34191 rubles.

Table 3. Capital investments for modernization of the thermal scheme of the energy block.

\begin{tabular}{|l|c|c|}
\hline \multicolumn{1}{|c|}{ Name } & Quantity & Cost \\
\hline Pipe $\mathrm{d}_{\mathrm{y}} 32 \mathrm{~mm}($ VGP 32*3) & $40 \mathrm{~m}$ & 1705 \\
\hline Pipe $\mathrm{d}_{\mathrm{y}} 50 \mathrm{~mm}($ VGP 50*3.5) & $15 \mathrm{~m}$ & 2778 \\
\hline Valve $15 \mathrm{c} 22 \mathrm{nzh} \mathrm{d}_{\mathrm{y}} 32 \mathrm{P}_{\mathrm{y}} 40$ & $4 \mathrm{pcs}$ & 12400 \\
\hline Valve 15c22nzh dy $50 \mathrm{P}_{\mathrm{y}} 40$ & $2 \mathrm{pcs}$ & 10000 \\
\hline Installation work & - & 7308 \\
\hline Total: & - & $\mathbf{3 4 1 9 1}$ \\
\hline
\end{tabular}

In the production and technical department of CHP10 , technical and economic indicators of the operation of

\footnotetext{
${ }^{3}$ MetallEnergoHolding Irkutsk // MetallEnergoHolding Group of Companies [Electronic Resource]. URL: http://www.metalloprokat-38.ru (15.12.2020).

4 Compensation equipment and valves in Novosibirsk [Electronic resource]. URL: https://www.apk-nsk.ru (15.12.2020)

${ }^{5}$ Gondar A.V., Trofimov Yu.V., Shar B.I., Osipov O.B. Basic prices for the repair of energy equipment, adequate for the functioning of the competitive market for repair and re-equipment services. M, 2006. [Electronic Resource].

URL: https://meganorm.ru/Data2/1/4293831/4293831699.htm (15.12.2020).

${ }^{6}$ Trofimov Yu.V., Shar B.I. RD 153-34.1-20.607-2002. Methodological guidelines for the formation of estimates and calculations for the repair of power equipment. M, 2002. [Electronic Resource]. URL:
} https://meganorm.ru/Data1/39/39532/index.htm (15.12.2020). power unit No. 5 for 2019 were obtained. This data is presented in table 4.

Table 4. Technical and economic indicators of energy block No. 5 for 2019.

\begin{tabular}{|l|c|}
\hline \multicolumn{1}{|c|}{ Indicator } & Value \\
\hline Working hours, hours & 4679 \\
\hline Electricity generation, $\mathrm{kW} \cdot \mathrm{h}$ & 499441394 \\
\hline $\begin{array}{l}\text { Specific consumption of conventional } \\
\text { fuel, gram of conventional fuel / kWh }\end{array}$ & 391,3 \\
\hline $\begin{array}{l}\text { The price of conventional fuel, rubles / } \\
\text { ton of conventional fuel }\end{array}$ & 2137,76 \\
\hline
\end{tabular}

Knowing the duration of operation of power equipment, it is possible to determine the annual coefficient of its extensive use $\beta$. This coefficient characterizes the use of equipment by the time spent in operation and is determined by the following formula:

$$
\beta=\frac{T_{a}}{T_{c}}=\frac{4679}{8760}=0.534
$$

where $T_{a}$ is the actual working time, $T_{c}$ is the calendar time, the number of hours per year.

It should be noted that the $\beta$ for 2019 can be considered as an average indicator of the use of the considered power plant over the past decade. This is due to the fact that at the beginning of the last decade, the $\beta$ coefficient was equal to $0.35-0.40$, and since 2014 it has increased to a value of $0.65-0.85$ due to a decrease in the hydroelectric potential of Lake Baikal and, as a result, the redistribution of electricity generation from hydrogenation to coal generation.

The indicators of economic efficiency of the proposed modernization of the heat scheme are are shown in Table 5. From Table, we can observe that when the equipment is operating for a year with $\beta=0.534$, the payback period for the proposed modernization of the thermal scheme will be 5.5 months. The cost savings for the first year of operation, taking into account the return on investment and depreciation costs, will amount to 18,423 rubles.

Table 5. Indicators of energy efficiency of energy block thermal scheme modernization.

\begin{tabular}{|l|c|}
\hline \multicolumn{1}{|c|}{ Indicator, units of measurement } & Value \\
\hline $\begin{array}{l}\text { Reduced specific fuel consumption, gram } \\
\text { of conventional fuel } / \mathrm{kW} \cdot \mathrm{h}\end{array}$ & 0,052 \\
\hline $\begin{array}{l}\text { Fuel economy for the year, ton of } \\
\text { conventional fuel }\end{array}$ & 25,971 \\
\hline Additional capital investments, rubles & 34191 \\
\hline Additional depreciation costs, rubles & 2906 \\
\hline Economic impact, \% & 153,9 \\
\hline Payback period, year & 0,461 \\
\hline
\end{tabular}




\section{Conclusions}

In the current thermal scheme of the power unit No. 5 of the CHP-10 of LLC "Baikal Energy Company", a number of heat flows were identified that reduce the efficiency of its operation. The identification of heat losses in the current scheme, as well as the identification of ways to modernize in order to reduce them, were carried out using the methods of analyzing the effectiveness of technical decision-making and mathematical modeling methods.

The evaluation of the effectiveness of the adopted technical solutions was carried out using variant calculations made on the developed and adjusted to the current state of the mathematical model of the power unit. Using the configured mathematical model, the necessary unmeasured and operational parameters of the thermal scheme of the power plant and economic efficiency indicators were calculated. This approach can be applied to other power plants in order to find ways to improve their efficiency.

The proposals presented by the authors will increase the efficiency of the equipment under study while maintaining operational reliability without significant investment in real-world operation. The proposed set of technical solutions was agreed with the key managers of the departments of the CHP-10 and a conclusion was received on the possibility of their implementation. The proposed measures will lead to a reduction in fuel consumption with the same electricity generation, which will increase the energy efficiency of the power unit.

The work was carried out within the framework of the draft state task (no. FWSE-2021-0005) of the program of basic research of the Russian Federation for the period from 2021 till 2030.

\section{References}

1. Vedruchenko VR, Zhdanov NV, Kulkov MV. Choice of criterion of the estimation of efficiency of development and reconstruction of the thermal schema of power setting. Vestnik Sibirskoj gosudarstvennoj avtomobil'no-dorozhnoj akademii $=$ The Russian Automobile and Highway Industry Journal Vestnik SibADI. 2008;7:60-64 p. (In Russ.)

2. Kler AM, Tyurina EA. Optimization studies of power plants and complexes. Novosibirsk: Geo; 2016, 298 p. (In Russ.)

3. Gutorov VF, Simoyu LL, Efros EI. Methods for enhancing the economic efficiency of steam-turbine installations of cogeneration stations. Teploenergetika $=$ Thermal Engineering. 2001;6:32-37. (In Russ.)

4. Lupov NS. Operating principle of ejector. Omskij nauchnyj vestnik $=$ Omsk Scientific Bulletin. 2015;2:167- 168. (In Russ.)

5. Lazarev LYa, Sokolov VS, Fadeev VA, Chizhov VV. Upgrading options of high-power turbine low pressure cylinders. Elektricheskie seti. Available from: https://leg.co.ua/arhiv/generaciya/variantymodernizaciicnd-turbin-bolshoy-moschnosti.html [Accessed 12th December 2020]. (In Russ.)
6. Merkulov VA, Marchenko EM. Effect of condensing device operation on turbine plant efficiency depending on power plant load. In: Radioelektronika, elektrotekhnika, energetika: tezisy dokladov IX Mezhdunarodnoj nauchnotekhnicheskoj konferencii studentov $\mathrm{i}$ aspirantov $=$ Radio electronics, electrical engineering, power engineering: abstracts of IX International scientific and technical conference of students and postgraduates: in 3 vol. Vol. 3. 4-5 March 2003, Moscow. Moscow: MEI; 2003, p. 148-149. (In Russ.)

7. Moshkarin AV, Kopsov AYa, Velikorossov VV, Taran OE, Platov AI. Thermal efficiency of surface HD polyethylene 2 replacement with a mixing one. In: Trudy Ivanovskogo gosudarstvennogo energeticheskogo universiteta. Iss. 3. Ivanovo: Ivanovo State Power Engineering University; 1999, p. 30-32. (In Russ.)

8. Alekseyuk VE, Maksimov AS, Safronov PG. Improved identification methods for thermal power equipment mathematical models. Vestnik Irkutskogo gosudarstvennogo tehnicheskogo universiteta = Proceedings of Irkutsk State Technical University. 2019;23(3):503-515. (In Russ.) https://doi.org/10.21285/1814-3520-2019-3-503-515

9. Alekseiuk V. Improving the efficiency of the three-stage technique of mathematical model identification of complex thermal power equipment. In: ENERGY-21 - Sustainable Development \& Smart Management: E3S Web of Conferences. 2020;209. https://doi.org/10.1051/e3sconf/202020903002

10. Alexeyuk VE. An improved technique for identification of mathematical models of thermal power equipment. Energy Systems Research. 2018;1(3):53-60. https://doi.org/10.25729/esr.2018.03.0007

11. Kler AM. Effective methods of circuit-parametric optimization of complex thermal power plants: development and application. Novosibirsk: Geo; 2018, 145 p. (In Russ.)

12. Kler AM, Zharkov PV, Epishkin NO. Parametric optimization of supercritical power plants using gradient methods. Energy. https://doi.org/10.1016/j.energy.2019.116230

13. Kler AM, Potanina YuM, Marinchenko AY. Cooptimization of thermal power plant flowchart, thermodynamic cycle parameters, and design parameters of components. $\quad$ Energy. 2020;193. https://doi.org/10.1016/j.energy.2019.116679

14. Baghsheikhi M, Sayyaadi H. Real-time exergoeconomic optimization of a steam power plant using a soft computing-fuzzy inference system. Energy. 2016;114:868-884.

https://doi.org/10.1016/j.energy.2016.08.044

15. Wang Ligang, Yang Yongping, Dong Changqing, Morosuk T, Tsatsaronis G. Parametric optimization of supercritical coal-fired power plants by MINLP and differential evolution. Energy Conversion and Management. 2014;85:828-838. https://doi.org/10.1016/j.enconman.2014.01.006

16. Wang Chaojun, He Boshu, Yan Linbo, Pei Xiaohui, Shinan Chen. Thermodynamic analysis of a low-pressure economizer based waste heat recovery system for a coal-fired power plant. Energy. 
2014;65:80-90.

https://doi.org/10.1016/j.energy.2013.11.084

17. Boyaghchi FA, Molaie H. Sensitivity analysis of exergy destruction in a real combined cycle power plant based on advanced exergy method. Energy Conversion and Management. 2015;99:374-386. https://doi.org/10.1016/j.enconman.2015.04.048

18. Suresh MVJJ, Reddy KS, Ajit Kumar Kolar. ANN-GA based optimization of a high ash coal-fired supercritical power plant. Applied Energy. 2011;88(12):4867-4873.

https://doi.org/10.1016/j.apenergy.2011.06.029

19. Sobolev SP. K-160-130 HTGZ Steam turbine. Moscow: Energiya; 1980, 192 p. (In Russ.)

20. Aronson KE, Blinkov SN, Brezgin VI, Brodov YuM, Kupcov VK, Larionov ID, et al. Power plant heat exchangers. Ekaterinburg: Ural Federal University; 2015. Available from: https://openedu.urfu.ru/files/book/ [Accessed 12th December 2020]. (In Russ.)

21. Kler AM, Dekanova NP, Tyurina EA, Korneeva ZR. Thermal power systems: optimization studies. Novosibirsk: Nauka; 2005, 236 p. (In Russ.)

22. Kler AM, Dekanova NP, Skripkin SK. Et al. Mathematical modeling and optimization in the problems of thermal power plant operational control. Novosibirsk: Nauka, Siberian enterprise RAS; 1997, 120 p. (In Russ.)

23. Novickij PV, Zograf IA. Estimation of measurement result errors. Leningrad: Energoatomizdat, Leningradskoe otdelenie; 1991, 303 p. (In Russ.)

24. Kobzar' AI. Applied mathematical statistics. For engineers and scientists. Moscow: Fizmatlit; 2012, 816 p. (In Russ.)

25. Zabuga FV. Using power unit mathematical model for its technological scheme modernization. In: Sistemnye issledovaniya $\mathrm{v}$ energetike: trudy molodyh uchenyh Instituta sistem energetiki im. L.A. Melent'eva SO RAN = System research in power engineering: works of young scientists of Melentiev Energy Systems Institute SB RAS. Iss. 48. Irkutsk: Melentiev Energy Systems Institute of the Siberian Branch of the Russian Academy of sciences; 2016, p. 51-56. (In Russ.) 